\title{
PENGARUH SENAM PROLANIS DALAM MENURUNKAN TEKANAN DARAH PADA LANSIA DENGAN HIPERTENSI
}

\author{
Maksuk*1 $^{1}$, Sherli Shobur ${ }^{1}$ Yusneli, ${ }^{2}$ \\ ${ }^{1}$ Jurusan Keperawatan Poltekkes Kemenkes Palembang, Sumatera Selatan Indonesia \\ ${ }^{2}$ Jurusan Analis Kesehatan Poltekkes Kemenkes Palembang, Sumatera Selatan Indonesia \\ (email penulis korespondensi: maksuk@poltekkespalembang.ac.id)
}

\section{THE EFFECT OF PROLANIS EXCERCISE TO DECREASE BLOOD PRESSURE IN ELDERLY WITH HIPERTENTION}

Info Artikel: Diterima: 10 Oktober 2020 Revisi: 30 November 2020 Disetujui: 30 Desember 2020

\begin{abstract}
ABSTRAK
Latar Belakang:Hipertensi merupakan penyakit tidak menular yang saat ini semakin meningkat terutama pada kelompok lansia. Penelitian ini bertujuan untuk mengimplementasikan senam prolanis dalam menurunkan tekanan darah pada lansia dengan hipertensi.

Metode: Penelitian ini merupakan penelitian eksperimen semu dengan desain One Group Pre testpost test. Penelitian dilakukan di Puskesmas Pegayut Kabupaten Ogan Ilir bulan Agustus November 2020. Data dikumpulkan menggunakan kuesioner dan tekanan darah diukur menggunakan tensi meter yang dilakukan sebelum dan setelah senam prolanis. Sampel sebanyak 31 responden dan merupakan total populasi. Analsis data uji menggunakan statistik pair t test.

Hasil:hasil analisis univariat menunjukkan bahwa klasifikasi lansia yaitu hipertensi tingkat 1 sebanyak $74,2 \%$ dan hipertensi tingkat 2 sebanyak $25,8 \%$, sedangkan uji statistik menggunakan pair $t$ test (nilai $\mathrm{p}=0,0005$ ) menunjukkan bahwa ada perbedaan tekanan darah sebelum dan setelah implementasi senam prolanis yang dilakukan lansia saat mengikuti Posyandu Lansia di Puskesmas Pegayut.
\end{abstract}

Kesimpulan: Senam prolanis merupakan latihan fisik yang dapat dilakukan lansia untuk membantu menurunkan tekanan darah jika dilakukan secara rutin dan benar.

Kata kunci : Senam Prolanis, Lansia, Hipertensi

\section{ABSTRACT}

Background: Hypertension is a non-communicable disease which is currently increasing, especially in the elderly group. This study aims to implement prolanic exercise in lowering blood pressure in elderly people with hypertension.

Methods: This study was a quasy experiment study with One Group Pre-test-post-test design. The research was conducted at the Public Health Center Pegayut, Ogan Ilir Regency from August to November 2020. The data were collected using a questionnaire and blood pressure was measured using a digital tension meter which was carried out before and after prolanis exercise. The sample was total population of 31 respondents. Data analysis was used a statistical pair t test.

Results: The results of univariate analysis showed that the classification of elderly i.e. hypertension level $1^{\text {st }}$ was $74.2 \%$ and hypertension level $2^{\text {nd }}$ was $25.8 \%$, whereas the results of paired t test with $p$ value $=0.0005$. It mean that there were differences in blood pressure before and after the implementation of prolanic exercises carried out by the elderly while attending the Elderly Posyandu at Pegayut Health Center

Conclusion: Prolanis exercise was a physical exercises that could be helped to decrease blood pressure of elderly if they are doing regularly.

Keywords: Prolanis Excercise, Elderly, Hypertension 


\section{PENDAHULUAN}

Hipertensi merupakan penyakit tidak menular yang lebih disebabkan oleh gaya hidup (life style) dan sering kenal dengan istilah "the silent killer" karena sering tanpa keluhan, sehingga penderita tidak tahu kalau dirinya mengalami hipertensi. ${ }^{1}$ Hipertensi saat ini mengalami peningkatan setiap tahunnya termasuk pada kelompok lansia dan diprediksi populasi lansia terus mengalami peningkatan. ${ }^{2}$ Peningkatan jumlah lansia harus mendapat perhatian khusus pada lansia yang mengalami suatu proses menua terutama terkait dengan masalah penyakit degeneratif pada lansia termasuk salah satunya hipertensi.

Setiap tahun jumlah penderita hipertensi mengalami peningkatan, berdasarkan hasil Riskesdas 2018 menunjukkan prevalensi Penyakit Tidak Menular mengalami peningkatan dibandingkan Riskesdas 2013, salah satunya hipertensi, hasil pengukuran tekanan darah, hipertensi mengalami kenaikan dari $25,8 \%$ menjadi $34,1 \%$. ${ }^{3}$ Pada tahun 2018 jumlah penderita hipertensi berumur $>15$ tahun di Provinsi Sumsel sebanyak 5.572.379 orang, di Kabupaten Ogan Ilir sebesar 541.796 penderita hipertensi. ${ }^{4}$

Peningkatan kasus hipertensi disebabkan oleh beberapa faktor antara lain kebiasaan hidup atau perilaku kebiasaan mengkonsumsi natrium yang tinggi, kegemukan, stres, merokok, dan minum alkohol. ${ }^{5}$ Adapun tingginya prevalensi hipertensi juga disebabkan gaya hidup yang tidak sehat seperti kurangnya olahraga/aktivitas fisik, kebiasaan merokok dan mengkonsumsi makanan yang tinggi kadar lemaknya. ${ }^{6}$ Aktivitas fisik yang dilakukan secara rutin terbukti berhubungan secara signifikan dalam menurunkan tekanan darah. ${ }^{7}$

Dengan semakin meningkatnya kasus hipertensi terutama pada kelompok lansia, maka upaya pencegahan dan penanggulangan penyakit faktor risiko hipertensi sangat penting dilakukan melalui Program Pengelolaan Penyakit Kronis (Prolanis) dengan melibatkan Peserta yang berada di Fasilitas Kesehatan dengan tujuan untuk mencapai kualitas hidup yang optimal. $^{8}$ Beberapa kegiatan Prolanis diantaranya pemeriksaan kesehatan, edukasi dan senam prolanis. Pemeriksaan kesehatan dengan pengukuran tekanan darah secara rutin di puskesmas dan kegiatan penyuluhan kesehatan sebagai upaya untuk meningkatkan pengetahuan dalam mencegah penyakit hipertensi.

Melalui penyuluhan tentang pola hidup sehat lansia meningkat dari kurang baik menjadi sangat baik di Desa Wonoasri Kecamatan Grogol Kabupaten Kediri. ${ }^{9}$ Selain itu upaya Prolanis dalam meningkatkan aktifitas fisik lansia melalui senam lansia juga membantu meningkatkan kerja jantung dan memperlancar peredaran darah. Studi terkait senam lansia yang dilakukan secara rutin oleh lansia di Posyandu Lansia Dusun Banaran Playen Gunung Kidul dapat menurunkan tekanan darah secara signifikan. ${ }^{10}$

Senam lansia terbukti membantu menurunkan tekanan darah lebih cepat pada penderita hipertensi yang menjalani pengobatan farmakologis, dibandingkan penurunan tekanan darah pada penderita hipertensi yang hanya mendapatkan pengobatan secara farmakologis saja di desa Kemuning Kabupaten Jember. ${ }^{11}$ Senam lansia yang dilakukan secara aktif oleh lansia di Puskesmas Lompoe Pare-Pare menunjukkan penurunan tekanan darah. ${ }^{12}$ Senam lansia merupakan merupakan suatu kegiatan yang telah dilakukan secara terprogam di fasilitas kesehatan tingkat pertama atau puskesmas dalam bentuk kegiatan mingguan di posyandu lansia, kegiatan ini dilakukan untuk meningkatkan aktifitas lansia.

Aktivitas fisik dan latihan olah raga sangat penting dilakukan secara rutin dan teratur oleh lansia terutama yang menderita hipertensi untuk membantu efisiensi kerja jantung. Oleh karena itu, melalui program posyandu lansia di wilayah kerja puskesmas meningkatkan aktivitas fisik lansia sehingga lansia termotivasi untuk mengikuti kegiatan dibawa binaan puskesmas melalui posyandu lansia.

Penelitian ini bertujuan untuk meningkatkan aktivitas fisik melalui senam prolanis untuk membantu menurunkan hipertensi pada lansia. 


\section{METODE}

Penelitian ini merupakan penelitian quasy experiment dengan desain pre experiment design One Group Pre test-post test dimana pada desain ini membandingkan nilai tekanan darah sistol dan diastole pre test yaitu sebelum dilakukan senam prolanis dan nilai post test yaitu setelah dilakukan senam prolanis. Populasi penelitian adalah seluruh lansia yang hadir di kegiatan tersebut sebanyak 31 orang dan semuanya dijadikan sampel penelitian (total populasi). Penelitian ini dilakukan di Puskesmas Pegayut Kabupaten Ogan Ilir pada bulan Agustus - Desember 2020.

Intervensi senam prolanis dilakukan selama empat minggu pada saat kegiatan lansia

\section{HASIL}

Hasil uji normalitas data menggunakan Shapiro Wilk diperoleh nilai $p>0,05$, ini bararti distribusi data normal. Hasil analisis mengikuti posyandu lansia yang dikasanakan setiap hari Kamis di Puskesmas Pegayut. Tekanan darah diukur sebelum senam menggunakan tensimeter digital easy touch, setelah itu dilakukan senam prolanis selama 1015 menit dan selanjutnya setelah 30 menit senam dalakukan pengukuran tekanan darah. Kegiatan senam di monitor oleh peneliti dan penanggung jawab kegiatan di Puskesmas. Sebelumnya data tekanan darah dilakukan uji normalitas data menggunakan Shapiro Wilk. Selanjutnya data dianalisis menggunakan analisis univariat dan bivariat dengan uji $\mathrm{t}$ berpasangan (pair t test).

karakteristik dan tekanan darah responden dijelaskan pada Tabel 1 dibawah ini:

Tabel 1. Distribusi Karakteristik dan Tekanan Darah Responden $(n=31)$

\begin{tabular}{|c|c|c|}
\hline Variabel & $\mathbf{n}$ & Persentase (\%) \\
\hline \multicolumn{3}{|l|}{ Jenis Kelamin } \\
\hline - Pria & 15 & 48,4 \\
\hline - Wanita & 16 & 51,6 \\
\hline \multicolumn{3}{|l|}{ Pendidikan } \\
\hline$-\mathrm{SD}$ & 26 & 83,9 \\
\hline - SMA & 5 & 16,1 \\
\hline \multicolumn{3}{|l|}{ Pekerjaan } \\
\hline - Petani & 25 & 80,6 \\
\hline - $\quad$ Buruh & 5 & 16,2 \\
\hline - $\quad$ Pabrik Padi & 1 & 3,2 \\
\hline \multicolumn{3}{|l|}{ Tekanan Darah } \\
\hline - $\quad$ Hipertensi Tingkat 1 & 23 & 74,2 \\
\hline - $\quad$ Hipertensi Tingkat 2 & 28 & 25,8 \\
\hline \multicolumn{3}{|l|}{ Umur (tahun) } \\
\hline Mean \pm SD & $62,2 \pm 8,5$ & \\
\hline Median (P25th-P75th) & $63(55-70)$ & \\
\hline \multicolumn{3}{|l|}{ Lama Tinggal (tahun) } \\
\hline Mean \pm SD & $47,9 \pm 16,9$ & \\
\hline Median (P25th-P75th) & $50(40-57)$ & \\
\hline \multicolumn{3}{|c|}{ Tekanan Darah Sistole (mmHg) } \\
\hline Mean \pm SD & $153,5 \pm 24,8$ & \\
\hline Median (P25th-P75th) & $147(136-164)$ & \\
\hline \multicolumn{3}{|c|}{ Tekanan Darah Diastole (mmHg) } \\
\hline Mean \pm SD & $89,7 \pm 13,3$ & \\
\hline Median (P25th-P75th) & $89(80-97)$ & \\
\hline
\end{tabular}


Berdasarkan Tabel 1 bahwa rerata tekanan darah sistol dan diastol pada lansia sebesar 153,5/89,7 $\mathrm{mmHg}$ dan berdasarkan kategori tingkatan hipertensi pada lansia yaitu Hipertensi Tingkat I lebih banyak dibandingkan Hipertensi Tingkat 2.

\section{Tabel 2. Hasil Uji t Berpasangan (Pair t Test) Tekanan Darah Lansia Sebelum dan Setelah Senam Prolanis di Puskesmas Pegayut $(n=31)$}

\begin{tabular}{lccc}
\hline Tekanan Darah & Mean & Standar Deviasi & p value \\
\hline Sistole & & & \\
$\quad$ Sebelum & 153,5 & 24,8 & 0,0005 \\
$\quad$ Setelah & 146,9 & 22 & \\
Diastole & & & \\
$\quad$ Sebelum & 89,7 & 13,3 & 0,0005 \\
$\quad$ Setelah & 84,9 & 10,2 & \\
\hline
\end{tabular}

Berdasarkan Tabel 2 hasil analisis menggunaka uji $t$ berbapasangan menunjukkanbahwa rerata penurunan tekanan darah sistole sebelum dan setelah dilakukan senam prolanis sebesar $6,6 \mathrm{mmHg}$, sedangkan penurunan tekanan darah diastol sebesar 4,8

\section{PEMBAHASAN}

Berdasarkan hasil pengukuran tekanan darah baik sistole dan diastole yang diukur sebelum dan 30 menit setelah senam selama empat minggu menunjukkan penurunan yang sangat signifikan. Hasil kategori berdasarkan klasifikasi tekanan darah lansia yang paling banyak klasifikasi hiperten tingkat 1 . Hal ini sesuai klasifikasi hipertensi menurut Joint National Committe dimana klasifikasi tekanan darah hipertensi tingkat 1 apabila tekanan darah sistol 140-159 mmHg dan diastol 90 - 99 $\mathrm{mmHg}$, sedangkan hipertensi tingkat 2 apabila tekanan darah sistol $\geq 160 \mathrm{mmHg}$ dan diastol $\geq$ $100 \mathrm{mmHg} .{ }^{13}$ Faktor risiko penyebab hipertensi sangat bervariasi yaitu faktor yang tidak dapat diubah diantaranya umur, jenis kelamin dan riwayat keturunan hipertensi. Semakin bertambahnya umur seseorang, terjadi proses penuaan secara degeneratif dimana akan berdampak pada perubahan-perubahan pada diri manusia yaitu fisik, kognitif, perasaan, sosial dan sexual. ${ }^{14}$

Hasil penelitian menunjukkan bahwa lansia yang mengalami hipertensi lebih banyak bekerja sebagai petani dibandingkan yang bukan petani dan telah berdomisili cukup lama di kawasan pertanian Desa Pegayut, sedangkan berdasarkan tingkat pendidikan lebih banyak
mmHg. Hasil uji statistik diperoleh nilai $\mathrm{p}=$ 0,0005 , ini berarti bawah terdapat pengaruh yang signifikan penurunan tekanan darah sebelum dan setelah dilakukan senam prolanis pada lansia yang menderita hipertensi.

yang berpendidikan sekolah dasar. Oleh karena itu edukasi terkait sangat penting dilakukan secara rutin untuk meningkatkan pengetahuan lansia dan mendukung program Prolanis. Peningkatan tekanan darah pada lansia umumnya terjadi akibat penurunan fungsi organ pada sistem kardiovaskular. Selain itu, terjadi peningkatan resistensi pembuluh darah perifer ketika ventrikel kiri memompa, sehingga tekanan sistolik dan diastol meningkat. ${ }^{15}$

Proses penuaan secara fisiologis menyebabkan terjadi perubahan fisik dimana secara alamiah membuat lansia malas untuk melakukan aktivitas fisik, kondisi ini sebagai salah satu faktor risiko masalah kesehatan atau penyakit pada lansia termasuk hipertensi. Aktivitas fisik berhubungan secara signifikan dengan kejadian hipertensi di Kecamatan Kemuning Kota Palembang. ${ }^{7}$ Selan itu, aktivitas fisik sangat berpengaruh pada lansia dengan aktivitas kurang lebih banyak menderita hipertensi dibandingkan dengan aktivitas baik. ${ }^{16}$ Oleh karena itu penting dilakukan senam khusus untuk lansia sesuai program Prolanis yang salah satunya adalah olah raga/melakukan aktifitas fisik seperti senam lansia.

Senam lansia terbukti menurunkan tekanan darah lansia di Puskesmas Wara 
Palopo. ${ }^{17}$ Hal ini dibuktikan bahwa lansia yang dilakukan intervensi senam lansia sebelum dan setelah hipertensi dapat menurunkan tekanan darah secara signifikan setelah dilakukan pengukuran tekanan darah 30 menit setelah senam. ${ }^{18}$ Sesuai hasil penelitian di Panti Sosial Tresna Werda Jambi dilaporkan bahwa senam lansia terbukti dapat menurunkan tekanan darah secara signifikan. ${ }^{19}$ Senam lansia yang dilakukan secara teratur dapat memperlancar peredaran darah sehingga tekanan darah yang tinggi dapat kembali ke dalam batas normal. Hal ini terbukti pada lansia GMIM Anugerah di Desa Tumaratas 2 yang melakukan senam lansia secara teratur tekanan darahnya stabil bahkan terjadi penurunan secara signifikan. ${ }^{20}$

Selain itu, senam lansia yang dilakukan secara teratur dan rutin terbukti efektif dalam menurunkan tekanan darah lansia dengan hipertensi di Wilayah Kerja Puskesmas Bulu Kabupaten Sukoharjo. $^{21}$ Senam lansia juga dapat menurunkan tekanan darah sistolik dan diastolik sebelum dan sesudah latihan pada

\section{KESIMPULAN DAN SARAN}

Senam prolanis terbukti berpengaruh dalam menurunkan tekanan darah pada lansia yang menderita hipertensi, melalui senam lansia yang dilakukan secara rutin dan teratur sesuai program Prolanis di Puskesmas membantu meningkatkan aktivitas fisik lansia lansia.

Kegiatan ini senam prolanis ini sangat direkomendasikan untuk lansia dan diharapkan

\section{UCAPAN TERIMA KASIH}

Ucapan terima kasih disampaikan kepada Kepala dan staf Pukesmas Pegayut yang telah memfasilitasi kegiatan penelitian ini serta para

\section{DAFTAR PUSTAKA}

1. Kemenkes RI. (2017). Sebagian Besar Penderita Hipertensi Tidak Menyadarinya. Jakarta: Kementerian Kesehatan Republik Indonesia.

2. Kemenkes RI, 2019. Profil Kesehatan Indonesia 2019. https://pusdatin.kemkes.go.id/resources/do wnload/pusdatin/profil-kesehatanindonesia/Profil-Kesehatan-indonesia2019.pdf lansia di Desa Glagahwero Kecamatan Panti Kabupaten Jember. ${ }^{22}$ Penurunan tekanan darah lansia berpengaruh sesudah dilakukan senam prolanis pada lansia di Posyandu Lansia Ngudi Waras Kelurahan Temon. ${ }^{23}$ Senam Prolanis juga berpengaruh secara signifikan terhadap tekanan darah lansia yang menderita hipertensi di Bengkulu. ${ }^{24}$

Senam prolanis menggunakan seluruh otot tubuh dengan gerakan yang dinamis, ringan dan sederhana diiringi musik sehingga lebih mudah untuk diikuti lansia. Secara fisiologik pada lansia terjadi penurunan curah jantung dan peningkatan resistensi vaskuler perifer, tetapi pada lansia dengan hipertensi berbagai faktor berperan dalam meningkatkan curah jantung, sehingga menyebabkan peningkatan tekanan darah. Oleh karena itu, aktivitas fisik dan latihan olah raga sangat penting dilakukan secara rutin dan teratur oleh lansia terutama yang menderita hipertensi untuk membantu efisiensi kerja jantung.

para lansia dapat melakukannya secara mandiri untuk meningkatkan aktivitas fisik secara rutin dan teratur. Selain itu petugas puskesmas dalam melaksanakan kegiatan posyandu lansia agar diikuti dengan edukasi kepada lansia untuk membantu meningkatkan pengetahuan lansia dalam mencegah hipertensi.

lansia atas partisipasinya dalam kegiatan penelitian ini.

3. Kemenkes RI. (2018) Riset Kesehatan Dasar (RISKESDAS) Tahun 2018. Jakarta: Kementerian Kesehatan Republik Indonesia.

4. Dinas Kesehatan Sumsel, 2019. Profil Dinas Kesehatan Provinsi Sumatera Selatan,. https://dinkes.sumselprov.go.id/

5. Sartik, S., Tjekyan, R. S., \& Zulkarnain, M. (2017). Risk Factors And The Incidence Of Hipertension In Palembang. 
Jurnal Ilmu Kesehatan Masyarakat, 8(3), 180-191.

6. Ainun, A. S., Sidik, D., \& Rismayanti. (2014). Hubungan Gaya Hidup dengan Kejadian Hipertensi pada Mahasiswa di Lingkup Kesehatan Universitas Hasanuddin. UNHAS Repository. Retrieved from

http://repository.unhas.ac.id/handle/123456 789/10728

7. Maksuk M. (2012). Analisis Faktor Risiko Penyakit Hipertensi Pada Masyarakat Di Kecamatan Kemuning Kota Palembang Tahun 2012. JPP (Jurnal Kesehat Poltekkes Palembang);1(10).

8. Badan Pemeliharaan Jaminan Sosial. (2016). Panduan praktis PROLANIS (Program Pengelolaan Penyakit Kronis). Jakarta

9. Nugraheni, R., \& Oktaviasari, D. I. (2019). Pengabdian Masyarakat "Penyuluhan Pola Hidup Sehat untuk Mencegah Penyakit Hipertensi dan Senam Lansia" di Desa Wonoasri Kecamatan Grogol Kabupaten Kediri. In Prosiding (SENIAS) Seminar Pengabdian Masyarakat.

10. Aji, W. P. B., \& Isnaeni, Y. (2015). Pengaruh Senam Lansia terhadap Tekanan Darah pada Lansia Penderita Hipertensi di Posyandu Lansia Dusun Banaran 8 Playen Gunung Kidul (Doctoral dissertation, STIKES'Aisyiyah Yogyakarta).

11. Anwari, M., Vidyawati, R., Salamah, R., Refani, M., Winingsih, N., Yoga, D., ... \& Susanto, T. (2018). Pengaruh senam anti hipertensi lansia terhadap penurunan tekanan darah lansia di Desa Kemuningsari Lor Kecamatan Panti Kabupaten Jember. The Indonesian Journal of Health Science, 160-164.

12. Dayanti, I. (2019). Hubungan Senam Prolanis Terhadap Penurunan Tekanan Darah Pada Pasien Hipertensi Di UPTD Puskemas Lompoe Kota Parepare. JIKI Jurnal Ilmiah Kesehatan IQRA, 7(02), 5357.
13. JNC - VII, 2003, Joint National Committe on Prevention Detection, Evaluation, and Treatment or High Pressure VII/, http://p2ptm.kemkes.go.id/infographicp2ptm/hipertensi-penyakit-jantung-danpembuluh-darah/page/28/klasifikasihipertensi

14. Azizah \& Lilik Ma'rifatul, (2011). Keperawatan Lanjut Usia. Edisi 1. Yogyakarta : Graha Ilmu

15. Gunawan, D. (2009). Perubahan Anatomik Organ Tubuh Pada Penuaan, (online), (http://pustaka.uns.ac.id/?opt=1001\&menu =news\&option=detail\&nid=122, diakses 15 Januari 2012)

16. Adam L, 2019. Determinan Hipertensi Pada Lanjut Usia, Jambura Health and Sport Journal, 1, (2): 82-89.

17. Tulak, G. T. (2017). Pengaruh Senam Lansia terhadap Penurunan Tekanan Darah Lansia Penderita Hipertensi di Puskesmas Wara Palopo. Perspektif: Jurnal Pengembangan Sumber Daya Insani, 2(1), 169-172.

18. DI Banjar, K. A. J. A. (2012). Pengaruh Senam Lansia terhadap Tekanan Darah Lansia dengan Hipertensi pada Kelompok Senam Lansia di Banjar Kaja Sesetan Denpasar Selatan.

19. Izhar, M. D. (2017). Pengaruh senam lansia terhadap tekanan darah di panti sosial tresna werdha budi luhur jambi Jurnal Ilmiah Universitas Batanghari Jambi, 17(1), 204-210.

20. Sunkudon, M. C., Palandeng, H., \& Kallo, V. (2015). Pengaruh senam lansia terhadap stabilitas tekanan darah pada kelompok lansia gmim anugerah di desa tumaratas 2 Kecamatan Langowan Barat Kabupaten Minahasa. Jurnal Keperawatan, 3(1).

21. Zulaikha, I., Kasjono, H. S., \& Wijayanti, A. C. (2016). Efektifitas Senam Lansia Terhadap Penurunan Tekanan Darah Pada Lansia Hipertensi Di Wilayah Kerja Puskesmas Bulu Kabupaten Sukoharjo (Doctoral dissertation, Universitas Muhammadiyah Surakarta).

22. Rahmawati, L., \& Aizza, N. (2018). Pengaruh senam prolanis terhadap penurunan tekanan darah pada lansia di desa Glagahwero Kecamatan Panti Kabupaten Jember. The Indonesian Journal of Health Science, 150-154. 
(JPP) Jurnal Kesehatan Poltekkes Palembang

Vol. 15, No. 2, Desember 2020, eISSN 2654-3427

DOI: 10.36086/jpp.v15i1.616

23. Trisusilowati, I., Mulyaningsih, M., \& Hermawati, H. (2019). Pengaruh Senam Prolanis Terhadap Tekanan Darah Pada Lansia Di Posyandu Lansia Ngudi Waras Kelurahan Temon (Doctoral dissertation, Stikes'aisyiyah Surakarta).
24. Fahlevi, A. R., Riyadi, A., \& Mardiani, M. (2019). Senam Prolanis Menurunkan Tekanan Darah Lansia Penderita Hipertensi. Jurnal Keperawatan Raflesia, l(2), 119-128. 